\title{
Breaking dormancy of GF305 peach and Real Fino apricot trees during the evaluation of resistance to sharka (plum pox potyvirus)
}

\author{
P. Martínez-Gómez, F. DicentA**, J. EgeA \\ Departamento de Mejora y Patología Vegetal, CEBAS-CSIC, Apartado 4195, 30080 Murcia, Spain
}

(Received 9 March 2000; accepted 20 June 2000)

\begin{abstract}
In countries like Spain or France, where sharka (plum pox potyvirus) is not as widespread as it is in Greece or Central Europe, experiments to evaluate apricot resistance have to be carried out in controlled conditions using insect-proof greenhouses. One of the most important aspects of such growth conditions is the application of periods of artificially induced dormancy in cold chambers so that tree species from temperate zones can undergo the necessary endodormancy-breaking step. In the experiment described in this paper, GF305 peach and Real Fino apricot seedlings were exposed to artificial periods of cold $\left(7^{\circ} \mathrm{C}\right)$ and darkness lasting 3 to 12 weeks (between 504 and 2016 hours of cold) in order to determine the optimum period for subsequent good vegetative growth. After removal from the cold chamber, the plants were placed in a greenhouse and weekly recordings were made of the percentage of leaf buds sprouted and vegetative growth. The optimal periods were found to be 5 weeks ( 840 hours of cold) for GF305 and 8 weeks (1344 hours of cold) for Real Fino.
\end{abstract}

\section{Prunus armeniaca L. / peach / apricot / artificial dormancy}

Résumé - Levée de dormance du pêcher GF305 et de l'abricotier Real Fino pendant l'évaluation de la résistance à la sharka (plum pox potyvirus). Dans des pays comme la France ou l'Espagne, où la sharka n'est pas aussi répandue qu'en Grèce ou en Europe Centrale, les expériences pour évaluer la résistance de l'abricotier doivent être conduites dans des conditions contrôlées en utilisant des serres indemnes d'insectes. Un des aspects les plus importants des ces conditions de culture est la nécessité d'appliquer des périodes d'induction artificielle de dormance pour que ces arbres des zones tempérées puissent passer l'étape indispensable de la levée de dormance. Dans l'expérience décrite, des plantules du pêcher GF305 et de l'abricotier Real Fino ont été exposées à des périodes artificielles de froid $\left(7^{\circ} \mathrm{C}\right)$ et d'obscurité durant 3 à 12 semaines (entre 504 et 2016 heures de froid) pour définir la période optimale permettant une bonne croissance végétative subséquente. À la sortie de la chambre froide, les plantes ont été placées en serre et des mesures hebdomadaires ont été faites du pourcentage de bourgeons de feuilles démarrés et de la croissance végétative. Les périodes optimales ont été de 5 semaines ( 840 heures de froid) pour GF 305 et de 8 semaines (1344 heures de froid) pour Real Fino.

Prunus armeniaca L. / pêcher / abricotier / dormance artificielle

Communicated by Jan Stenlid (Uppsala, Sweden)

* Correspondence and reprints

fdicenta@natura.cebas.csic.es 


\section{Introduction}

Sharka (plum pox potyvirus, PPV) is one of the principal limiting factors in apricot cultivation in those areas which are affected by this virus. It can only be controlled by uprooting diseased trees and planting healthy certified trees, and definitively by growing new resistant cultivars. The evaluation of resistance in new cultivars is one of the most important steps in apricot breeding programs. In countries such as Spain and France, where the disease is not as widespread as it is in Greece or Central Europe, the evaluation of resistance to PPV must be carried out under controlled conditions in insect-proof greenhouses $[3,7,19]$.

Such greenhouse studies of woody plants from temperate zones necessitate the periodic induction and breaking of endodormancy [18]. The use of artificial cold periods also makes possible the study of more than one cycle per year [19], thus shortening the evaluation period. Furthermore, plants emerging from dormancy sprout rapidly, favouring virus multiplication and the appearance of symptoms in susceptible cultivars [3].

The chilling requirements of woody plants have to be fully satisfied if dormancy breaking is to result in the desired vegetative growth and if the fruit-bearing capacity is to be fulfilled $[5,10,11$, $12,14,16]$. Moreover, this cold period must neither be too long nor too short for dormancy breaking to occur since both would have a negative effect on subsequent vegetative growth $[5,11,21]$. Another factor to be taken into account is the vegetative maturity of a plant before it is exposed to cold $[14,23]$.

In the experiment described, we studied the influence of the length of an artificially induced cold period in a cold chamber $\left(7^{\circ} \mathrm{C}\right)$ on the endodormancy breaking and the subsequent growth of GF305 peach and Real Fino apricot seedlings, two of the most commonly used rootstocks in PPV resistance studies under controlled conditions.

\section{Materials and methods}

Seedlings of GF305 peach and Real Fino apricot were used in this study. GF305 peach is characterised by its susceptibility to fruit viruses including plum pox potyvirus [4] and for this reason is widely used as a rootstock in experiments to evaluate the resistance of different Prunus species to PPV [2, 15]. Real Fino is widely used as a rootstock in apricot cultivation [13] and has been described as being susceptible to sharka [20]. On the other hand, Real Fino shows a moderate to high chilling requirement in comparison with other apricot cultivars [9].

Both GF305 and Real Fino seedlings were cultivated in two litre pots and exposed to periods of cold lasting between 3 and 12 weeks (504 to 2016 chill units), in a cold chamber in darkness at $7{ }^{\circ} \mathrm{C}$, the most effective temperature for breaking dormancy in fruit species $[8,12]$. The plants were introduced into the cold chamber at the end of October, after 4 months of growth in a greenhouse, at the end of their vegetative cycle. For both species and for each of the 10 cold treatments five plants were studied, making a total of 100 plants.

At the end of the cold treatments the plants were placed in a greenhouse and pruned to $30 \mathrm{~cm}$, leaving about 12 vegetative buds (GF305) or 7 vegetative buds (Real Fino) per plant. The temperature within the greenhouse varied from $15^{\circ} \mathrm{C}$ to $35^{\circ} \mathrm{C}$ during the cycle studied. For 3 months after the plants had been taken from the cold chamber, two characteristics were recorded weekly: the percentage of vegetative buds sprouted per plant and the vegetative growth. The vegetative growth was considered as a general score of the vegetative aspect of the plant, using a scale from 0 (when plants did not sprout) to 5 (when vegetative appearance was optimum).

A bifactorial analysis of variance was made of the final percentage of sprouted leaf buds and of the final vegetative growth of each species, for each treatment, using a randomised design. In addition, a unifactorial analysis of variance was made of the sprouted leaf buds and the final vegetative growth of the different cold treatments in each species separately, grouping the means by Tukey's test [22]. 


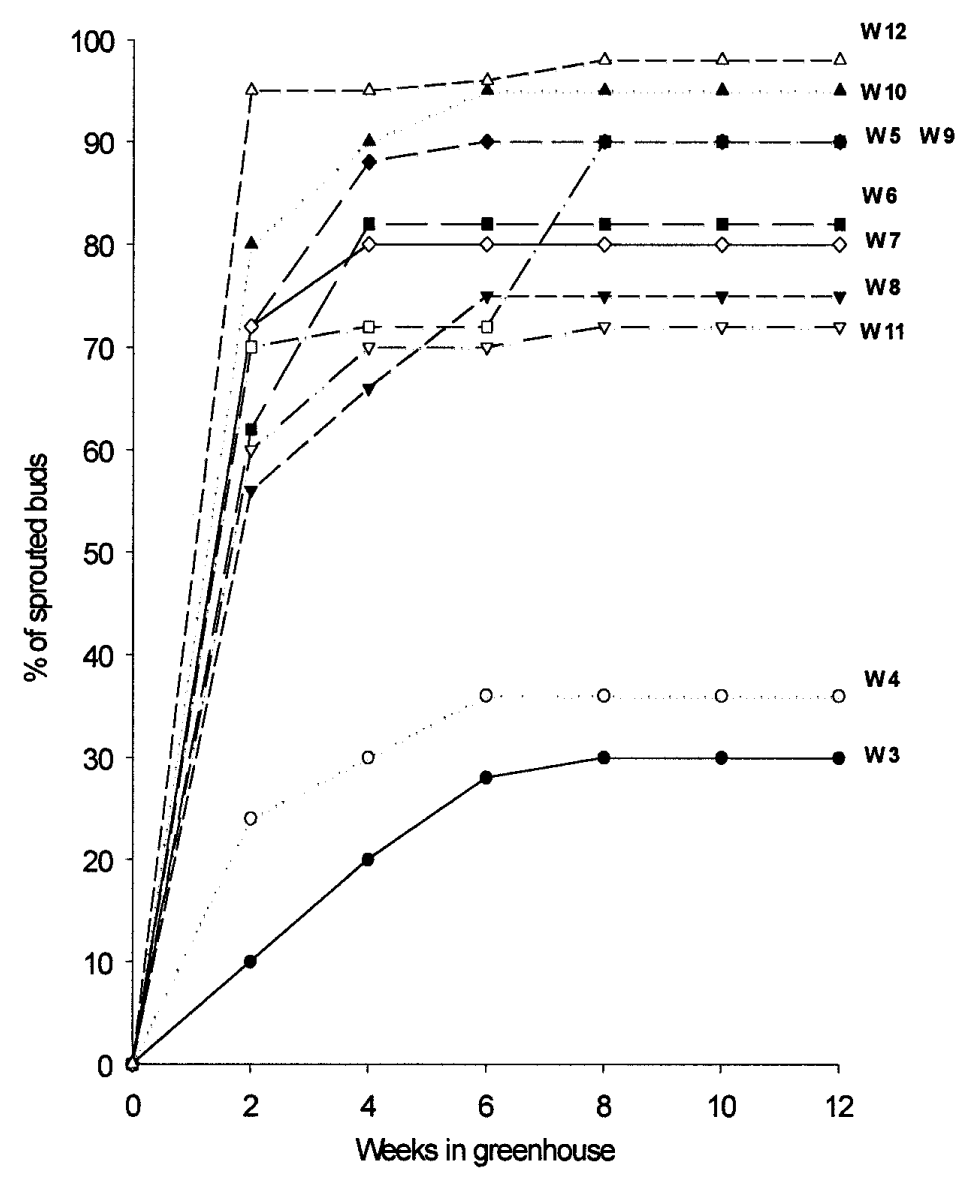

Figure 1. Time course of percentage of sprouted leaf buds in GF305 peach seedlings grown in a greenhouse for 12 weeks after exposure to a temperature of $7^{\circ} \mathrm{C}$ in a cold chamber for different periods ( 3 to 12 weeks). W3 $=504$ chill units, W4 $=675$, W5 $=840$, $\mathrm{W} 6=1008, \mathrm{~W} 7=1176, \mathrm{~W} 8=1344, \mathrm{~W} 9=1512$, $\mathrm{W} 10=1680, \mathrm{~W} 11=1848, \mathrm{~W} 12=2016$.

\section{Results and discussion}

\subsection{GF305 peach}

Sprouted leaf buds: An increasing number of leaf buds sprouted with time, most of those which were going to sprout having done so by weeks 4 to 8 (Fig. 1). The analysis of variance detected significant differences for this characteristic 12 weeks after the cold treatment (Tab. I). Tukey's test did not detect significant differences for the percentage of leaf buds sprouted after three months for the plants subjected to cold treatment lasting 5 to 12 weeks (Tab. II).

After 5 weeks (840 chill units) GF305 plants already showed signs of breaking dormancy, with a high final percentage of sprouted leaf buds
(Tab. II). This time (5 weeks), must therefore be considered optimum and the most efficient for dormancy breaking, since it was both short and gave the best results.

Vegetative growth: This characteristic also increased gradually with time in the greenhouse up

Table I. ANOVA $(\operatorname{Pr}>\mathrm{F} \times 100)$ of the final percentage of sprouted leaf buds and vegetative growth after 12 weeks cultivation in the greenhouse of GF305 peach and Real Fino apricot seedlings, following different cold treatments at $7{ }^{\circ} \mathrm{C}$ for between 3 (W3) and 12 weeks (W12).

\begin{tabular}{lcc}
\hline & GF305 peach & Real Fino apricot \\
\hline Sprouted leaf buds (\%) & 0.01 & 0.01 \\
Vegetative growth & 0.05 & 0.01 \\
\hline
\end{tabular}


Table II. Final percentage of sprouted leaf buds and final vegetative growth in GF305 peach and Real Fino apricot seedlings after exposure to $7^{\circ} \mathrm{C}$ in a cold chamber.

\begin{tabular}{|c|c|c|c|c|c|}
\hline \multirow[b]{2}{*}{ Cold treatment } & \multirow[b]{2}{*}{ Chill units } & \multicolumn{2}{|c|}{ GF305 peach } & \multicolumn{2}{|c|}{ Real Fino apricot } \\
\hline & & $\begin{array}{c}\text { Sprouted } \\
\text { buds }(\%)^{1}\end{array}$ & $\begin{array}{l}\text { Vegetative } \\
\text { growth }^{1}\end{array}$ & $\begin{array}{l}\text { Sprouted } \\
\text { buds }(\%)^{1}\end{array}$ & $\begin{array}{l}\text { Vegetative } \\
\text { growth }^{1}\end{array}$ \\
\hline W3 & 504 & $30 \quad b$ & $2.6 b c$ & $56 \quad b c d$ & $3.2 a b c$ \\
\hline W4 & 675 & $36 b$ & $2.2 \quad c$ & $16 e$ & $1.2 \quad c$ \\
\hline W5 & 840 & $90 a$ & $4.8 a$ & $d e$ & 3.0 \\
\hline W6 & 1008 & $82 a$ & $5.0 a$ & $d e$ & $3.0 \quad b c$ \\
\hline W7 & 1176 & $80 a$ & $4.6 a b$ & $48 \quad c d$ & $2.8 \quad b c$ \\
\hline W8 & 1344 & $75 a$ & $3.6 a b c$ & $72 a b c$ & $5.0 a$ \\
\hline W9 & 1512 & $90 a$ & $4.1 a b c$ & $76 a b c$ & $4.7 a b$ \\
\hline W10 & 1680 & $94 a$ & $4.0 a b c$ & $80 a b$ & $4.6 a b$ \\
\hline W11 & 1848 & $72 a$ & $3.0 a b c$ & $98 a$ & $3.9 a b$ \\
\hline W12 & 2016 & $98 a$ & $2.8 b c$ & $96 a$ & $3.6 a b$ \\
\hline
\end{tabular}

${ }^{1}$ Values followed by different letters show significant differences according to Tukey's test, with a 5\% level of significance.

Figure 2. Time course of vegetative growth (measured on a scale from 0 to 5 ) in GF305 peach seedlings grown in a greenhouse for 12 weeks after exposure to a temperature of $7{ }^{\circ} \mathrm{C}$ in a cold chamber for different periods ( 3 to 12 weeks). W3 $=504$ chill units, W4 $=675$, W $5=840$, W $6=1008, \mathrm{~W} 7=1176$, $\mathrm{W} 8=1344, \mathrm{~W} 9=1512, \mathrm{~W} 10=1680, \mathrm{~W} 11=1848$, $\mathrm{W} 12=2016$.

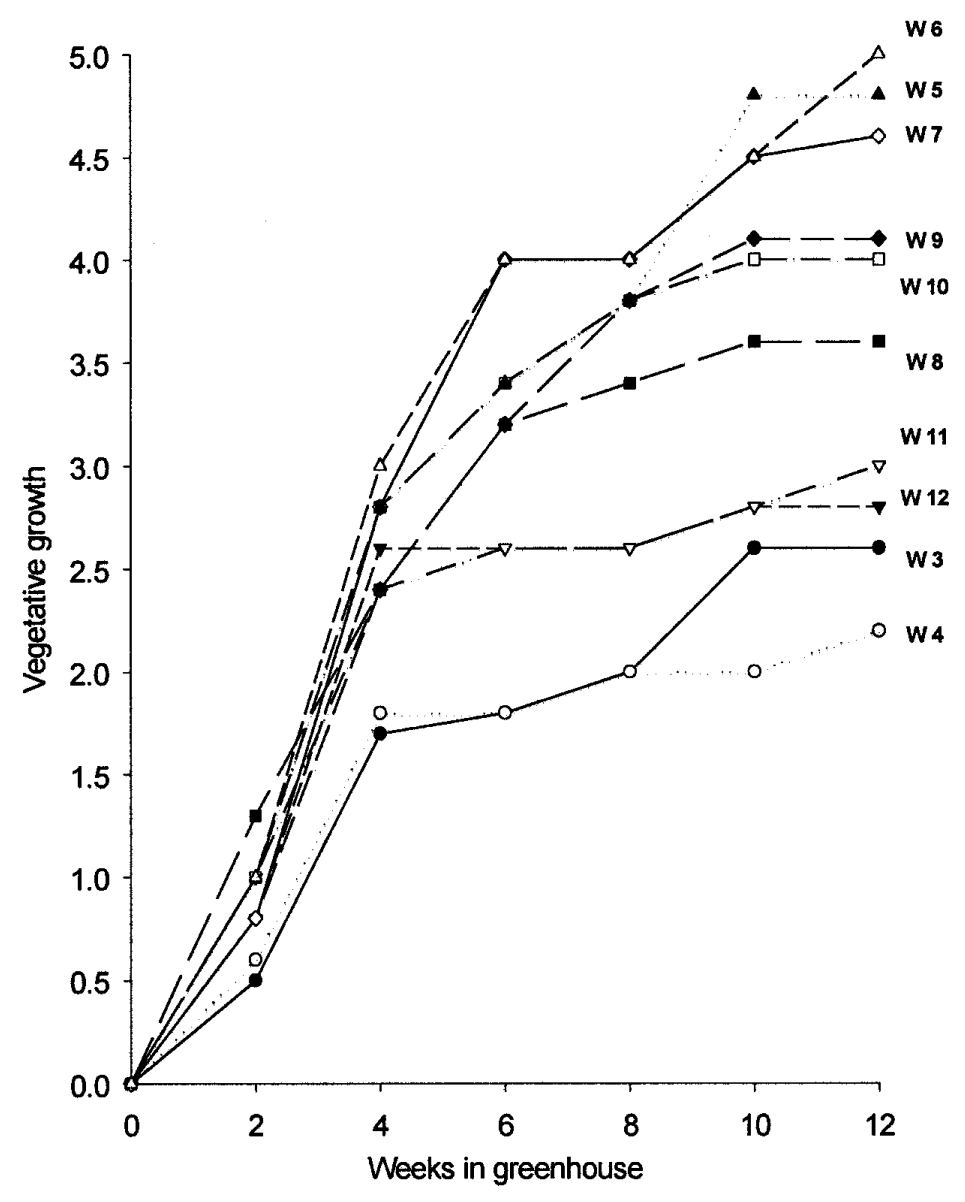




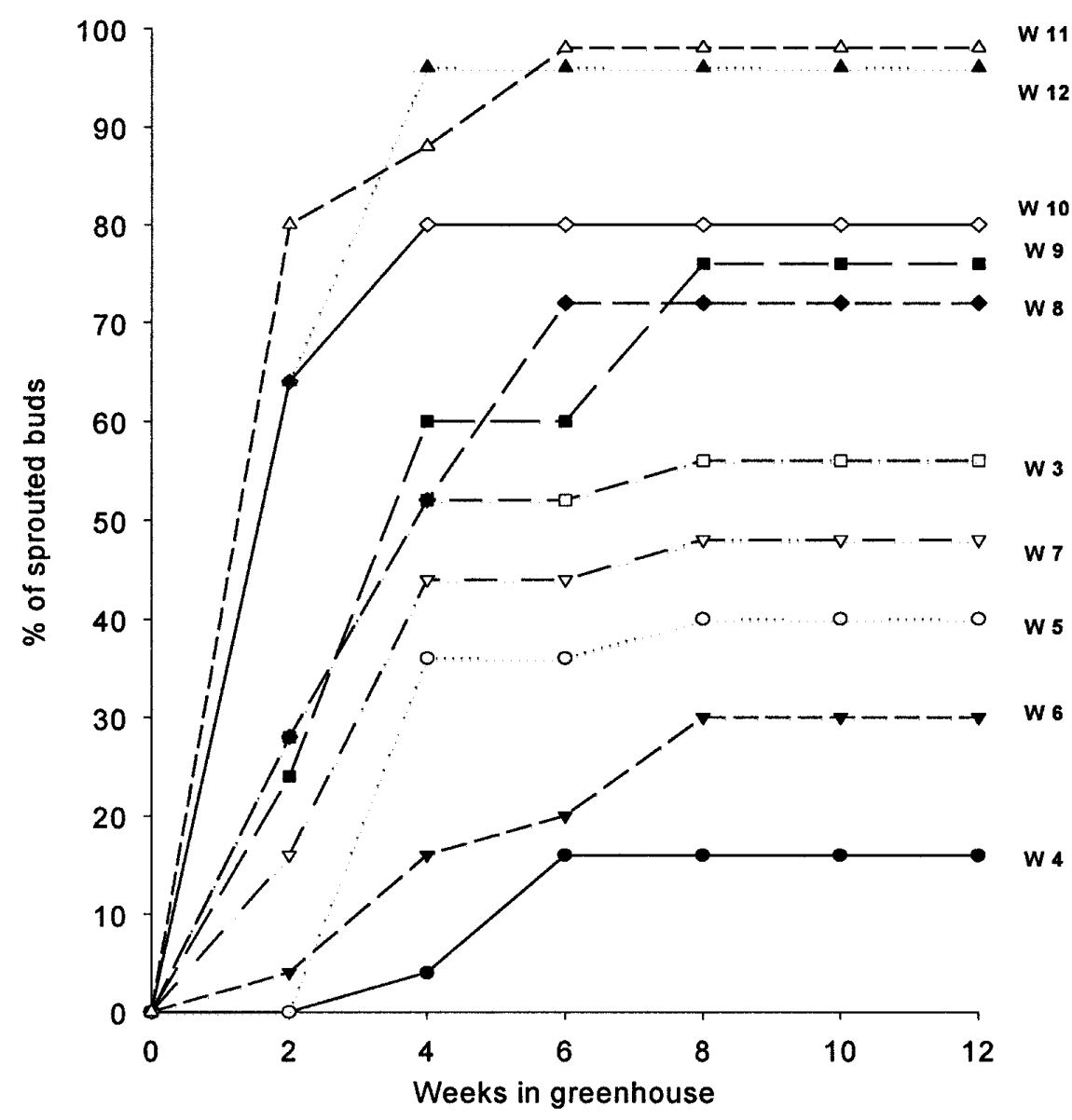

Figure 3. Time course of percentage of sprouted leaf buds in Real Fino apricot seedlings grown in a greenhouse for 12 weeks after exposure to a temperature of $7^{\circ} \mathrm{C}$ in a cold chamber for different periods (3 to 12 weeks). W3 $=504$ chill units, $\mathrm{W} 4=675, \quad \mathrm{~W} 5=840, \mathrm{~W} 6=1008$, $\mathrm{W} 7=1176, \mathrm{~W} 8=1344, \mathrm{~W} 9=1512$, $\mathrm{W} 10=1680, \mathrm{~W} 11=1848, \mathrm{~W} 12=2016$. to 12 weeks, although more rapidly up to week 4 or 6 (Fig. 2). The analysis of variance detected significant differences for this characteristic, as it did for the percentage of sprouted buds (Tab. I). It can be seen that periods of 5 to 11 weeks in the cold chamber ( 840 to 1848 chill units) are grouped as the best results in Tukey's test (Tab. II), longer and shorter periods leading to less vegetative growth.

\subsection{Real Fino apricot}

Sprouted leaf buds: Most Real Fino leaf buds had sprouted by weeks 6 to 8 , which is about two weeks later than GF305 (Fig. 3). The analysis of variance detected significant differences for this characteristic after 12 weeks in the greenhouse, following the end of the cold treatment (Tab. I).
The data point to the medium-high chilling requirements of Real Fino in order to undergo dormancy breaking. The shortest periods of cold treatment were clearly insufficient and only a few leaf buds sprouted afterwards. The highest percentage of dormancy breaking in the leaf buds was observed after only 1344 chill units (Tab. II, Fig. 3). Since the results obtained after periods of 8 (1344 chill units) to 12 (2016 chill units) weeks were statistically similar, the shorter treatment ( 8 weeks) was considered as the optimum. Unlike GF305, the final percentage of sprouted leaf buds varied greatly in Real Fino, according to the length of each cold treatment.

Vegetative growth: As in the case of the GF305 peach, vegetative growth increased gradually with time after the plants were taken out from the cold 


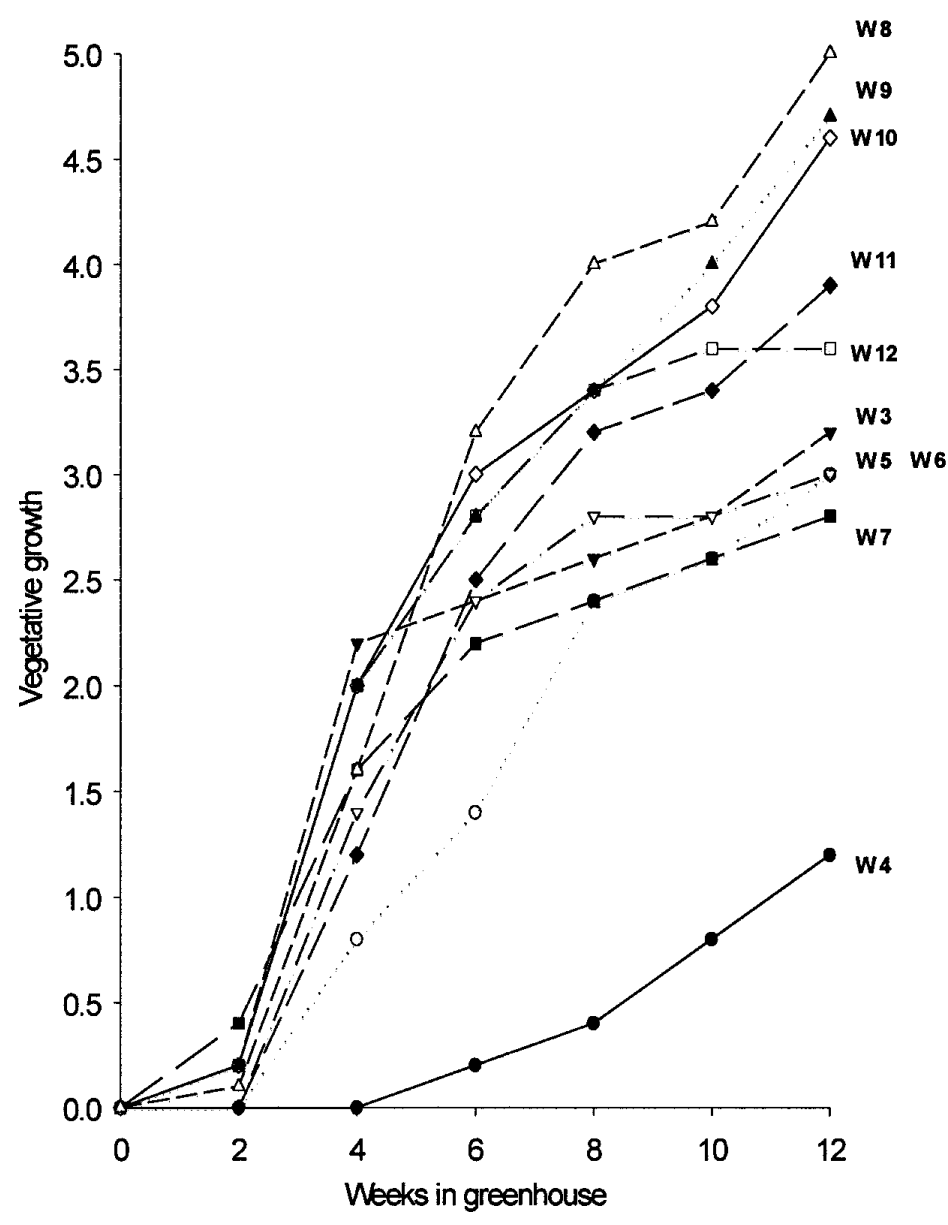

Figure 4. Time course of vegetative growth (measured on a scale from 0 to 5) in Real Fino seedlings grown in a greenhouse for 12 weeks after exposure to a temperature of $7^{\circ} \mathrm{C}$ in a cold chamber for different periods ( 3 to 12 weeks). W3 $=504$ chill units, $\mathrm{W} 4=675$, W5 $=840, \mathrm{~W} 6=1008, \mathrm{~W} 7=1176, \mathrm{~W} 8=1344$, $\mathrm{W} 9=1512, \mathrm{~W} 10=1680, \mathrm{~W} 11=1848, \mathrm{~W} 12=2016$. chamber, but did not stabilise (Fig. 4). The analysis of variance detected significant differences for this characteristic after 12 weeks in the greenhouse, following the cold treatment (Tab. I). As in the case of the percentage of buds sprouted, 8 weeks (1344 chill units) was the most suitable time for encouraging vegetative growth (Tab. II, Fig. 4). These chilling requirements are less than those applied by Dicenta and Audergon (1998) in Stella apricot seedlings. Stella is an apricot cultivar from North America characterised by high chilling requirements.

It is clear that the short periods of cold treatment had a distinct lack of effect on the plants in treatments W3 and W4 (Tab. II, Fig. 4). The probable explanation for this is that plants subjected to W3 treatment did not enter into a phase of total endodormancy [1], while a four week cold treatment was insufficient to break the dormancy. These results would indicate that the chilling requirements for breaking the dormancy of Real Fino seedlings would be slightly lower than those observed.

The different chilling requirements observed in GF305 and Real Fino were obviously determined by their genotypes, but chilling requirements could also be influenced by the vegetative state of these cultivars just before the cold treatment, as reported by Hill and Campbell [17]. Furthermore, Walser et al. [23] stated that defoliation was a sign of the beginning of dormancy. Usually, and also in our experiment, the time of defoliation is different in Real Fino, which in this study had most of its 
leaves at the beginning of the cold treatment, while GF305 had no leaves at this point.

We conclude that the most effective periods of cold treatment, at $7{ }^{\circ} \mathrm{C}$, for optimal subsequent vegetative growth are 5 weeks for the GF305 peach and around 8 weeks for the Real Fino apricot. Similarly, when evaluating PPV resistance, the GF305 used as inoculum source, and those still not grafted with the apricot, should be subjected to cold for 5 weeks, while the GF305 already grafted with the apricots to be evaluated should be exposed to cold for around 8 weeks.

\section{References}

[1] Amling H.J., Amling K.A., Onset, intensity and dissipation of rest in several pecan cultivars, J. Am. Soc. Hort. Sci. 30 (1980) 536-540.

[2] Audergon J.M., Morvan G., A rapid method for assessing the sensivity of apricot to plum pox virus, XXIII International Horticultural Congress, Firenze, 1990, p. 46.

[3] Audergon J.M., Morvan G., Dicenta F., Chastellier G., Karayiannis I., A method to determine the susceptibility of apricot cultivars to plum pox virus, Acta Hort. 384 (1995) 575-579.

[4] Bernhard R., Marénaud C., Sutic D., Le pêcher GF305 indicateur polyvalent des virus des espèces à noyau, Ann. Phytopathol. 1 (1969) 603-617.

[5] Chandler W., Influence of the rest period on opening of buds of fruit trees in spring and on development of flower buds of peach trees, J. Am. Soc. Hort. Sci. 30 (1934) 180-186.

[6] Dicenta F., Audergon J.M., Inheritance of resistance to plum pox potyvirus (PPV) in "Stella" apricot seedlings, Plant Breed. 117 (1998) 579-581.

[7] Dosba F., Orliac S., Dutranoy F., Maison P., Massonie G., Audergon J.M., Evaluation of resistance to Plum pox virus in apricot trees, Acta Hort. 309 (1992) 211-219.

[8] Egea J., Necesidades de frío en frutales de hoja caduca. Estado de la cuestión, Frut. Profesional 24 (1989) 19-23.

[9] Egea J., El albaricoquero en España: Panorámica varietal, Frut. Profesional 96 (1998) 49-55.
[10] Egea J., Burgos L., Fructification problems in continental apricot cultivars growing under Mediterranean climate, J. Hort. Sci. Biotech. 73 (1998) 107-110.

[11] Erez A., Lavee S., The effect of climatic conditions on dormancy development of peach buds. I. Temperature, J. Am. Soc. Hort. Sci. 96 (1971) 711-714.

[12] Erez A., Couvillon G.A., Characterization of the influence of moderate temperatures on rest completion in peach, J. Am. Soc. Hort. Sci. 112 (1987) 677-680.

[13] Felipe A.J., Patrones para frutales de pepita y hueso, Ediciones Técnicas Europeas, Barcelona, 1989.

[14] Fuchigami L.M., Motze M., Weiser C.J., The relationship of vegetative maturity to rest development and spring bud-break, J. Am. Soc. Hort. Sci. 102 (1977) 450-452.

[15] Gabova R., Evaluation of peach and nectarine cultivars in Bulgaria for their resistance to plum pox potyvirus, EPPO Bull. 24 (1994) 755-760.

[16] Hauagge R., Cummins J.N., Age, growing temperatures, and growth retardants influence induction and length of dormancy in Malus, J. Am. Soc. Hort. Sci. 116 (1991) 116-120.

[17] Hill A.G.G., Campbel G.C.G., Prolonged dormancy of deciduous fruit trees in warm climates, Emp. J. Exp. Agric. 17 (1949) 259-264.

[18] Lang G.A., Early J.D., Martin G.C., Darnell R.L., Endo-, para-, and eco-dormancy physiological terminology and classification for dormancy research, HortSci. 22 (1987) 371-377.

[19] Martínez-Gómez P., Dicenta F., Evaluation of resistance to sharka in the breeding apricot program in CEBAS-CSIC in Murcia (Spain), Acta Hort. 488 (1999) 731-736.

[20] Martínez-Gómez P., Dicenta F., Evaluation of resistance of apricot cultivars to a Spanish isolate of plum pox potyvirus (PPV), Plant Breed. 119 (2000) 179-181.

[21] Richardson E.A., Seeley S.D., Walker R.D., A model for estimating the completion of rest for Red Haven and Elberta peach trees, HortSci. 9 (1974) 331-332.

[22] SAS/STAT User's Guide, SAS Institute, Caey, NC, USA, 1989.

[23] Walser R.H., Walker D.R., Seeley S.D., Effect of temperature, full defoliation, and gibberellic acid on the rest period of peach leaf buds, J. Am. Soc. Hort. Sci. 106 (1981) 91-94. 